\title{
Treasure Islands: biosecurity in the Hauraki Gulf Marine Park
}

\author{
Imogen E. Bassett ${ }^{1, *}$, Jeff Cook ${ }^{1}$, Finlay Buchanan ${ }^{2}$, James C. Russell ${ }^{3,4}$ \\ ${ }^{1}$ Auckland Council Biosecurity, Private Bag 92300, Auckland 1142, New Zealand \\ ${ }^{2}$ Department of Conservation, PO Box 32026, Devonport, Auckland, New Zealand \\ ${ }^{3}$ School of Biological Sciences, University of Auckland, Private Bag 92019, Auckland 1142, New Zealand \\ ${ }^{4}$ Department of Statistics, University of Auckland, Private Bag 92019, Auckland 1142, New Zealand \\ *Author for correspondence (Email: Imogen.Bassett@aucklandcouncil.govt.nz)
}

Published online: 12 January 2016

\begin{abstract}
Islands offer unique opportunities and challenges in biosecurity and conservation management. We review current and past island biosecurity within Tāmaki Makaurau-Auckland's 1.2 million ha Hauraki Gulf Marine Park (HGMP), which includes 30 island groups, many of which are inhabited. We highlight evolving challenges and changes in island biosecurity focus. Eradication of introduced mammals from islands in the HGMP has restored mammal pest-free status to around 16 islands/island groups, i.e. over half. However, eradications are only part of island biosecurity and require follow-up with on-going vector control, surveillance and incursion response. Almost 35\% of the population of Aotearoa-New Zealand lives in or around the HGMP, with hundreds of thousands of visitors to the islands each year, making human-mediated propagule pressure an important consideration in island biosecurity within the Park. The Treasure Islands public awareness campaign is an example of a multi-species, multi-agency approach to managing the human dimension of invasion risk. Data on introduced mammal incursions and reinvasions on predator-free islands highlight the role of both swimming and human-transport as vectors, and large inhabited islands elsewhere in the HGMP as reinvasion sources. Since 2000, biosecurity has prevented all but one incursion leading to full reinvasion. We highlight the crucial role of robust social science in supporting successful island biosecurity programmes in populous areas, and propose the Treasure Islands campaign as a case-study for providing insights into potential improvements in future use of social science in such programmes.
\end{abstract}

Key words: behaviour change; eradication; incursion response; island biosecurity; rodent invasion; social science; surveillance; vector control

\section{Introduction}

Island biota is typified by high levels of endemism, the absence of otherwise common taxonomic groups, and relatively low population sizes. These factors, among others, make island biota especially vulnerable to invasive species (Reaser et al. 2007). While islands may be particularly vulnerable to invasion, they are also uniquely defendable. The ocean is a powerful barrier to natural invasion by introduced species (Russell et al. 2004). Eradication, along with incursion prevention and response are all made easier by the geographic isolation of islands, reducing invasion risk. However, islands open to unmonitored public access also present considerable management challenges due to their very same remoteness (Atkinson 1973).

Propagule pressure, encompassing both the number of individuals per introduction event and the number of discrete introduction events, is a key component influencing pest establishment (Reaser et al. 2008). Islands vary in their risk of non-human mediated invasions, largely based on their degree of geographic isolation. Introduced mammals can swim kilometres to colonise offshore islands (Russell et al. 2004). Geographic isolation also determines invasion risk for wind- and bird-dispersed taxa such as weeds. However, although natural processes undoubtedly contribute to dispersal of many invasive species to islands, human-mediated dispersal represents a substantial, but potentially more manageable, source of propagule pressure to the islands. Each human visitor to an island presents a risk of transporting invasive species on their equipment, footwear, clothing and vessels, in addition to risks associated with commercial activities such as movement of buildings, plants and other nursery or landscaping supplies.

Island biosecurity is a complex suite of measures, including eradication, prevention measures (vector control), surveillance, and incursion responses (Russell et al. 2008b). Together these measures seek to remove existing populations of invasive species, minimise movement of invasive species to islands from which they are absent, and maximise early detection of and response to incursions to prevent population establishment. This paper reviews the components, changing nature and future needs of island biosecurity in the Hauraki Gulf. The 'Treasure Islands' public awareness campaign is highlighted as a globally important case-study of an integrated, multi-agency approach to public engagement and island biosecurity measures. Lessons from this programme are valuable for biosecurity programmes in populous regions worldwide.

\section{The Hauraki Gulf Marine Park}

The Hauraki Gulf (Figure 1) comprises a diverse range of ecosystems and geographical features, including 1.2 million ha of ocean, 30 major island groups and over 400 discrete 'islands', including rock stacks, reefs and sand bars (Lee 1999; Barbera 2012). These islands are home to one of the highest diversities of seabirds in the world (Gaskin \& Rayner 2013), and refuges for terrestrial birds, reptiles, invertebrates and plants (Diamond \& Veitch 1981; Towns et al. 2016). Recognition of the special nature and national significance of the Hauraki Gulf led to the establishment of the Hauraki Gulf Maritime Park in 1967 and later the Hauraki Gulf Marine Park (HGMP) in 2000. The Department of Conservation (DOC), 


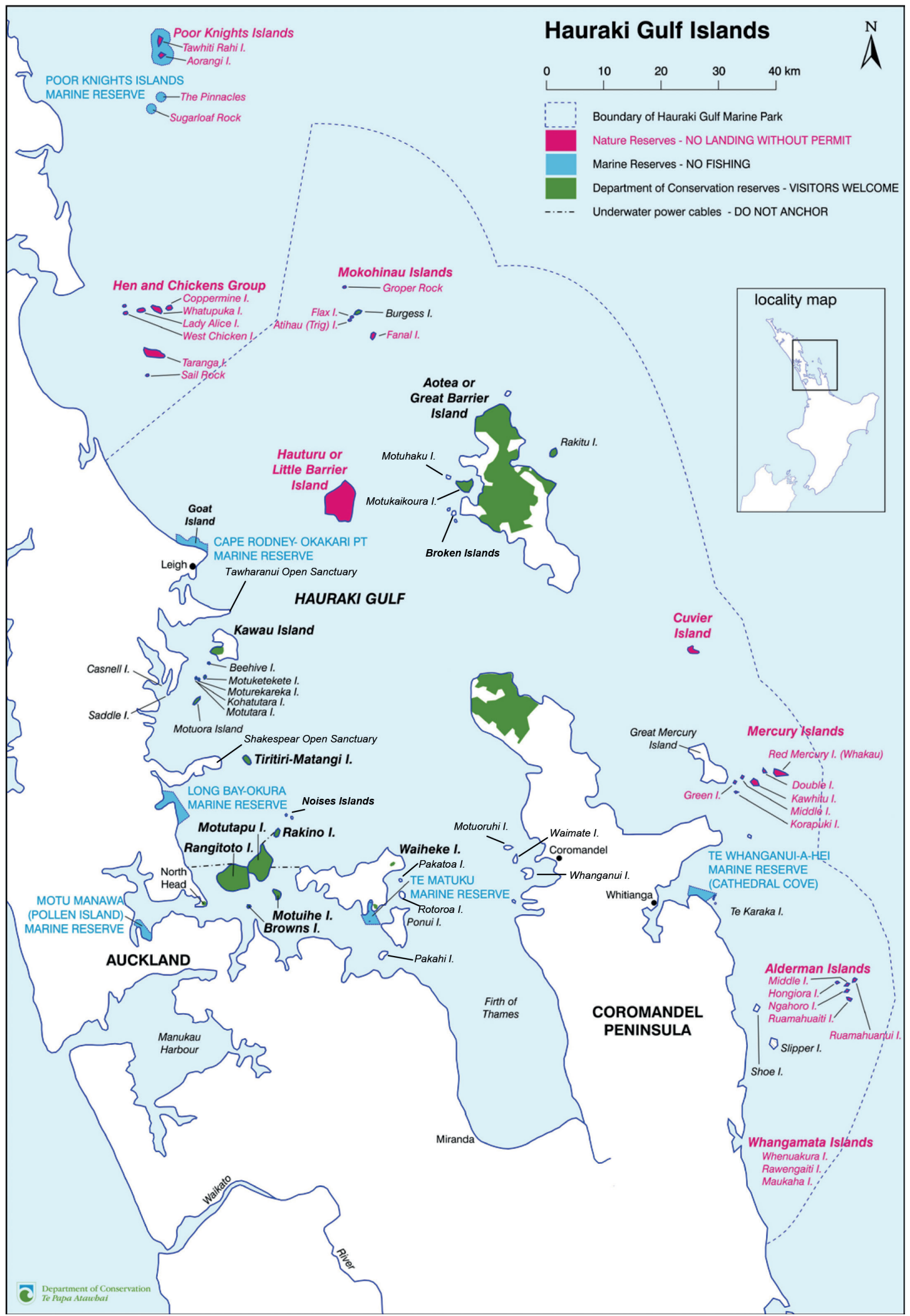

Figure 1: Boundaries of Hauraki Gulf Marine Park and locations of main island groups. Source: Hauraki Gulf Forum. 
Auckland Council and Waikato Regional Council all have management responsibilities within the HGMP. The HGMP Act 2000 provided for greater integration and consistency of administration of an important inter-regional resource. The HGMP is subject to site-led controls under Auckland's and Waikato's individual Regional Pest Management Strategy/ Plans (RPMS/P) ${ }^{1}$. These controls cover movement of buildings and a number of pest species in order to minimise vectoring of pests to and among islands. The RPMS/P also provide for some pest species to be managed to lower densities and/or with more onerous regulatory requirements on Hauraki Gulf islands and coastal mainland buffer zones than is afforded elsewhere in the Tāmaki Makaurau-Auckland and Waikato Regions for these species. DOC administers the Conservation Act 1987 and the Wildlife Act 1953, both of which mandate DOC's biosecurity role. DOC also administers a number of islands in the HGMP for the protection of their conservation values and enjoyment by visitors where the latter is compatible with the conservation purpose for which the land is held. This leads to some DOC-managed islands accepting public visitation and others not.

The HGMP also abuts Tāmaki Makaurau-Auckland, which is the most populous and sprawling city in AotearoaNew Zealand. Almost 35\% of the population of AotearoaNew Zealand, over 1.3 million people, live in or around the HGMP (Barbera 2012). The HGMP is heavily used by recreational and commercial vessels. In 2011, there were estimated to be over 13,500 yachts, launches and other personal water craft, and around 75,000 small craft (such as dinghies, canoes, small sailing boats and windsurfers) in the Tāmaki Makaurau-Auckland region (Leersynder 2012 cited by Hauraki Gulf Forum 2014). Substantial increases in the numbers of recreational craft are predicted in the coming decades (Leersynder 2012 cited by Hauraki Gulf Forum 2014). Each year, Ports of Auckland services over 1,400 cargo ships from 176 international ports (Ports of Auckland Limited 2015). In the $2014 / 5$ season, more than 257,000 passengers and crew are expected to pass through Ports of Auckland on cruise ships (Ports of Auckland Limited 2015). In addition to using the surrounding marine environment of the gulf, large numbers of people visit gulf islands each year. For example, Rangitoto receives around 100,000 visitors per year and Tiritiri Matangi receives at least 30,000 visitors. Several of the larger HGMP islands are also home to permanent human populations, including Waiheke (over 8000 residents), Aotea /Great Barrier (almost 900 residents) and Kawau (almost 100 residents) (Census Auckland 2015).

\section{Eradications}

A key focus of pest management on the HGMP islands has been eradication of invasive mammals (Appendix A Table 1). The first eradications of mammals from islands were of rabbits (Oryctolagus cuniculus) and goats (Capra hircus) that came to be considered as pests following their earlier introductions as a food resource. The first rodent eradication in the HGMP, indeed all of Aotearoa-New Zealand, was the removal of Norway rats (Rattus norvegicus) from one hectare Ruapuke/Maria Island in the Noises group, shortly after their

\footnotetext{
${ }^{1}$ Auckland currently has a Regional Pest Management Strategy (RPMS), but will soon be updating this to a Regional Pest Management Plan (RPMP), consistent with the recently released National Policy Direction for Pest Management. Waikato Regional Council has already updated their previous RPMS to an RPMP.
}

invasion. Commenced in 1959, the successful eradication was finally confirmed in 1964 (Russell \& Broome 2016). More recently Norway rats and kiore (Pacific rats; Rattus exulans) have been removed from HGMP islands since the 1980s, mice (Mus musculus) since the 1990s, and ship rats (Rattus rattus) since 2000 . Notable events in the history of mammal eradications include the repeatedly misdiagnosed reinvasion of the Noises throughout the 1980s and 1990s (Russell 2007) and rat eradication failure on Kaikoura Island in 2008 and annual reinvasion of its neighbouring islands (Fewster et al. 2011). Mammal eradications in the HGMP have to date culminated in the successful eradication of 10 vertebrate species from the 3,842 ha Rangitoto-Motutapu Island complex (Griffiths et al. 2015), which continues to operate as the Tàmaki Makaurau-Auckland region's largest farming venture (Table 1). Not all eradications are successful, with some failing and others being stopped prior to completion. In addition, rodent eradications are typically not declared complete until after a two-year stand-down period or sometimes have never been officially confirmed (Appendix A Table 2). Some of these earliest eradications are now documenting substantial species and ecosystems recoveries, such as removal of kiore from the Mokohinau (Ismar et al. 2014) and Mercury Islands (Towns et al. 2016).

\section{Biosecurity}

Pest eradication is not a stand-alone event and needs to be supported by on-going measures to prevent and respond to reinvasion. As the number of rat eradications increased in Aotearoa-New Zealand during the 1990s, so too did the number of rat reinvasions (Clout \& Russell 2008), and stoats have been found to be highly capable swimmers (King et al. 2014). Island biosecurity comprises a complex suite of measures seeking to remove existing populations of invasive species, minimise movement of invasive species to islands, maximise early detection of incursions and respond to detected incursions to prevent population establishment. Surveillance to detect incursions is necessary at departure and arrival points (e.g. wharves and marinas) and across all potential vectors (e.g. commercial and recreational boats) using a mixed tools approach to maximise detection. Surveillance for rodents on islands in the HGMP relies on a combination of lethal and non-lethal tools. The lethal tools include kill-traps and toxins, each of which has about $85 \%$ success intercepting incursions (Russell et al. 2008b). Non-lethal tools include monitoring devices such as tracking tunnels, waxtags or chew cards (Sweetapple \& Nugent 2011). All such devices can be combined, or exchanged, in 'rodent motels' (Russell et al. 2008b). Recent development of the DOC series of traps has created a trap suitable for both rats and stoats simultaneously, while Delilah rats are a caged rat (typically laboratory) used as a social attractant alongside other monitoring or control devices (Gsell et al. 2014; Shapira 2014). Detection dogs can be used effectively to complement traditional detection tools. Dogs have a success rate of over $80 \%$ for detecting rat presence, similar to that of traps and toxins (Gsell et al. 2010). Dogs also have the ability to locate individuals rapidly. For example, in 2008 Fin Buchanan (Island Biosecurity Ranger) and his rodent detection dog Jak located a Norway rat on Motuihe within an hour of landing on the island. In addition to their practical role, detector dogs can be of enormous value in raising the public profile of biosecurity. However, highly specialised training is required for both dogs and their handlers, and dogs are also relatively expensive to maintain, 
Table 1: Status of introduced mammals on islands and groups of the Hauraki Gulf Marine Park following Clout \& Russell (2006) and updates since (see Appendix A). Y = present, $\bullet=$ absent, $E=$ eradicated. $\wedge^{\wedge}=$ feral guinea pigs (eradicated), $\dagger=$ ongoing programme due to high reinvasion risk. Small islands and islets are excluded.

\begin{tabular}{|c|c|c|c|c|c|c|c|c|c|c|c|c|c|c|c|}
\hline Island & Deer & Pig & Goat & Cat & Wallaby & Possum & Rabbit & Ferret & Stoat & Weasel & Hedgehog & $\begin{array}{r}\text { Norway } \\
\text { rat }\end{array}$ & $\begin{array}{r}\text { Ship } \\
\text { rat }\end{array}$ & Kiore & Mice \\
\hline Mokohīnau group & • & • & $\mathrm{E}$ & • & • & • & • & • & • & - & • & • & • & $\mathrm{E}$ & \\
\hline Gt Barrier (Aotea) & - & Y & $\mathrm{E}$ & Y & • & • & Y & • & • & - & • & • & Y & $\mathrm{Y}$ & 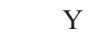 \\
\hline Gt Barrier (Rakitu/Arid) & • & $\mathrm{E}$ & $\mathrm{E}$ & • & • & • & • & • & • & • & • & • & $\mathrm{Y}$ & $\mathrm{Y}$ & \\
\hline Gt Barrier (Kaikōura) & $\mathrm{E}$ & - & • & • & • & • & • & - & • & - & • & • & Y & $\mathrm{Y}$ & \\
\hline $\begin{array}{l}\text { Te Hauturu-O-Toi } \\
\text { /Little Barrier }\end{array}$ & • & • & • & $\mathrm{E}$ & $\bullet$ & • & • & • & - & - & $\bullet$ & • & • & $\mathrm{E}$ & \\
\hline Hāwere/Goat & • & - & • & - & • & • & • & • & • & - & • & • & $\mathrm{E} \dagger$ & • & \\
\hline Kawau & • & - & • & $\mathrm{Y}$ & $\mathrm{Y}$ & $\mathrm{Y}$ & • & $\mathrm{Y}$ & $\mathrm{Y}$ & - & • & • & Y & • & \\
\hline Moturekareka \& Motutara & • & • & $\mathrm{E}$ & • & • & • & • & • & • & - & • & • & • & • & 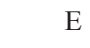 \\
\hline Motuketekete $^{\wedge}$ & • & • & • & • & • & • & • & - & - & - & • & • & • & • & 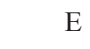 \\
\hline Te Haupa/Saddle & • & - & • & • & • & • & • & • & • & - & • & $\mathrm{E}$ & • & • & 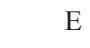 \\
\hline Motuora & • & • & • & • & • & • & • & - & • & - & • & • & • & - & \\
\hline Tiritiri Matangi & • & • & • & • & • & • & E & - & • & - & • & • & • & E & \\
\hline Rangitoto & $\mathrm{E}$ & • & • & $\mathrm{E}$ & E & E & E & • & $\mathrm{E}$ & - & $\mathrm{E}$ & • & E & $\mathrm{E}$ & \\
\hline Motutapu & $\mathrm{E}$ & - & • & $\mathrm{E}$ & $\mathrm{E}$ & $\mathrm{E}$ & $\mathrm{E}$ & • & $\mathrm{E}$ & - & $\mathrm{E}$ & • & $\mathrm{E}$ & $\mathrm{E}$ & \\
\hline Rakino & • & • & • & $\mathrm{Y}$ & • & • & • & • & • & - & • & $\mathrm{E}$ & • & • & \\
\hline The Noises & • & - & • & - & • & • & $\mathrm{E}$ & - & • & - & • & $\mathrm{E}$ & - & - & \\
\hline Motukorea/Browns & • & • & • & - & • & • & $\mathrm{E}$ & - & • & - & • & $\mathrm{E}$ & • & • & 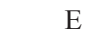 \\
\hline Motuihe & • & - & • & $\mathrm{E}$ & • & • & $\mathrm{E}$ & - & • & - & • & $\mathrm{E}$ & - & • & 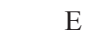 \\
\hline Waiheke & • & $\mathrm{Y}$ & Y & Y & • & • & $\mathrm{Y}$ & $\mathrm{Y}$ & $\mathrm{Y}$ & - & Y & Y & Y & • & 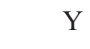 \\
\hline Tarahiki/Shag & • & $\cdot$ & • & • & • & • & • & - & • & - & • & $\mathrm{E}$ & • & • & \\
\hline Pakatoa & • & • & • & $\mathrm{Y}$ & • & • & • & - & • & - & • & $\mathrm{E}$ & • & - & 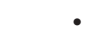 \\
\hline Rotoroa & • & - & • & • & • & • & • & - & - & - & • & $\mathrm{E}$ & • & • & 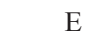 \\
\hline Pōnui/Chamberlins & • & - & • & Y & • & • & • & - & - & - & • & Y & Y & - & 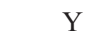 \\
\hline Pakihi/Sandspit & • & • & • & • & • & • & • & - & $\mathrm{E}$ & - & • & • & $\bullet$ & • & $Y$ \\
\hline Kāramuramu & • & • & • & • & • & • & • & - & • & - & • & $\mathrm{E}$ & • & • & $\mathrm{E}$ \\
\hline Whanganui & - & - & • & • & • & $\mathrm{Y}$ & $\mathrm{Y}$ & - & $\mathrm{Y}$ & - & Y & - & Y & • & \\
\hline Motutapere & - & - & • & • & - & $\mathrm{E}$ & • & • & $\mathrm{E}$ & - & • & • & $\mathrm{E}$ & • & 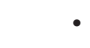 \\
\hline Waimate & - & - & • & • & - & • & • & - & $\mathrm{E}$ & - & • & • & • & • & \\
\hline Moturuhi & • & $\mathrm{E}$ & • & $\bullet$ & $\bullet$ & • & • & - & $\mathrm{E}$ & - & • & • & - & • & \\
\hline Motukawao group & - & • & • & • & • & • & Y & - & - & - & • & Y & Y & - & \\
\hline Repanga/Cuvier & • & • & E & $\mathrm{E}$ & • & • & • & - & • & - & • & $\bullet$ & $\bullet$ & $\mathrm{E}$ & \\
\hline Ahuahu/Great Mercury & • & • & • & $\mathrm{E}$ & • & • & • & - & - & - & • & - & $\mathrm{E}$ & $\mathrm{E}$ & \\
\hline Mercury group & • & • & • & - & • & • & E & - & • & - & • & • & • & $\mathrm{E}$ & \\
\hline Aldermen & - & • & • & • & • & • & • & - & • & - & • & • & - & $\mathrm{E}$ & \\
\hline Ohinau & • & • & • & • & • & • & E & - & • & - & • & • & • & $\mathrm{E}$ & \\
\hline Slipper group & • & • & • & • & • & • & Y & - & • & - & • & • & - & Y & \\
\hline Whangamata islands & • & • & • & • & • & • & • & - & • & - & • & E & • & • & $\mathrm{Y}$ \\
\hline
\end{tabular}

in comparison to other detection tools. All these combinations of tools have also had a $100 \%$ success rate at intercepting rat incursions into predator-fenced peninsula sanctuaries of the Tāmaki Makaurau-Auckland region, namely Tawharanui and Shakespear (M. Maitland pers. comm.).

Biosecurity has long been an issue in the HGMP (Atkinson 1973). Several islands have had re-establishment of rat populations, particularly on small islands in close proximity to larger islands (e.g. Aotea/Great Barrier and Waiheke) from which rats could not be eradicated (Appendix A Table 3). The function of Aotea/Great Barrier and Waiheke as source populations for invasions to other nearby islands underscores the importance of progressing management of invasive species on these islands, not only for benefits in their own right, but to protect investment in other pest-free islands. Many islands have also had incursions successfully intercepted (Appendix A Table 4) of mice (exclusively from boats), Norway rats (a mix of boats and swimming) and stoats (exclusively from swimming). One other notable swimming incursion was of an Asian short-clawed otter (Aonyx cinerea) 'Jin' who escaped from Auckland Zoo and was not re-captured for nearly one month. However, incursions of larger mammals which would 
not normally swim, by human transportation (i.e. on boats), have also been recorded. No clear trends are evident in the gender or time of year of incursions, suggesting dispersal and hence risk is not linked to season or sex-biased juvenile dispersal (see also Bagasra et al. 2016). Furthermore, it is likely that there have been additional incursions not leading to establishment, which have gone undetected. Therefore, all islands at all times are potentially at risk of population re-establishment in the absence of adequate surveillance and response.

Furthermore, population establishment is not a necessary precursor to substantial biodiversity impacts accruing from an invasion. Elsewhere in Aotearoa-New Zealand, incursions of single Norway rats have decimated reintroduced populations of shore plover (Thinornis novaeseelandiae) (Dowding \& O’Connor 2013). Equally rat-vulnerable species such as saddleback (Philesturnus carunculatus rufusater) and reptiles have already been reintroduced to a number of HGMP islands (Lambert et al.2005; Towns et al.2016). Accurate financial cost data are sparse for incursion responses but where available they suggest biosecurity responses typically run from thousands to tens of thousands of dollars depending on the level of pro bono labour and advice provided by volunteers, staff and experts. Standardised recording of cost data would allow valuable financial return on investment calculations for maintaining biosecurity in perpetuity.

Research, on both invasion ecology and management tools, is another important component contributing to improvements in island biosecurity. Through the 2000s experimental incursions and reinvasions of rodents were used to test and refine island biosecurity systems for rodents (Russell et al. 2008b). Experimental incursions of male Norway rats took place on Motuhoropapa (Russell et al. 2008a, 2010) and Motukorea/ Browns Island (Shapira et al. 2013), and experimental work on mice took place on Te Haupa/Saddle Island for male and female mouse incursions (MacKay 2011) and invasion (Nathan et al. 2013, 2015). Natural reinvasion of islands off the west coast of Aotea/Great Barrier have also allowed testing and development of molecular methods to discriminate rat reinvasion sources and eradication failure (Fewster et al. 2011) and biomarker methods to estimate reinvasion rates (Bagasra et al. 2016). These molecular methods have then also been applied to stoat incursions (Veale et al. 2012). Ongoing development of new pest control and eradication tools is required to supplement existing tools and support new initiatives (Russell et al. 2015).

\section{Treasure Islands}

Mitigation of the propagule pressure posed by movement of people and goods is a crucial component of the longterm maintenance of pest-free island status, in addition to on-going surveillance for incursions. Mitigating human propagule pressure requires public awareness and, crucially, that public awareness is translated into positive behaviour change to decrease vectoring risk. This latter point is not easily achieved; there are many examples of high public awareness of an environmental issue failing to translate into widespread pro-environmental behaviour change due to a lack of clear messaging around simple steps that individuals can take to address the problem, or a failure to address key 'barriers' to behaviour change (Fransson \& Garling 1999; McKenzie-Mohr 2000; Kalamas et al. 2014).

The intention to perform pro-environmental behaviour is approximately one third explained by a selfish weighing up of rewards versus punishments (Bamberg \& Moser 2007). Restoration projects in the HGMP leverage heavily off the 'rewards' which accrue to restoration participants, such as social interaction, increased environmental education, and opportunities to see rare wildlife and to watch landscapes be transformed positively through their actions (Ryan et al. 2001; Galbraith 2013). In contrast, many of the social consequences of island biosecurity are uncertain, involve substantial time lags between action and consequence, and accrue to the individual as a member of the community as a whole rather than the individual directly (Gattig \& Hendrickx 2007). For instance, preventing reinvasion preserves opportunities for future positive ecotourism/recreation experiences, while preventing costs associated with future pest management. Both these benefits accrue in the mid- to long-term across the community as a whole and may be difficult for the individual to identify as a direct consequence of their own actions. An additional problem is that benefits from biosecurity on pest-free islands may not be readily perceived as a 'reward' (because the pest status does not change), unless the public can make the link between long-term pest-free status and improved biodiversity outcomes.

DOC and Auckland Council address the risk of human transportation of pest species within the HGMP through the 'Treasure Islands' campaign(www.treasureislands.co.nz). This integrated, joint agency, multi-species approach encompasses islands owned or managed by both central and local government as well as private individuals. The Treasure Islands campaign was conceived as part of the planning process preceding the multi-species mammal eradication on Rangitoto-Motutapu, which of necessity had to consider the reinvasion risk associated with the islands' many visitors (Griffiths et al. 2015). At its inception the campaign had a rodent and ant focus, but it has subsequently broadened to include weed seeds, plague (rainbow) skinks (Lampropholis delicata) and kauri dieback disease (Phytothphora agathidicida; until recently known as Phytothphora taxon 'agathis'(Weir etal.2015)). The campaign also includes messages discouraging the taking of dogs and other pets to pest-free islands.

Treasure Islands material provides clear and simple messaging, not only of the problem but also the solutions: 'check your boat and gear'. A finite list of priority species to check for is also provided, ensuring that the task should remain manageable in people's minds. The Treasure Islands message is further tailored for transport providers, recreational boaties, island residents and commercial businesses transporting goods to the islands. Communication methods include: signage at entry and exit points to islands (Figure 2), plus all public boat ramps in the HGMP; detection dog visits to freight and passenger vessels; stickers on bait stations and traps; and the 'Pest-free Warrant' for commercial and non-commercial vessels and tourism operators. The Pest-free Warrant provides an accreditation system whereby businesses gain a marketing advantage by communicating biosecurity messages to their customers and applying biosecurity measures within their own operations. Over 40 organisations operating in the HGMP currently hold a Pest-free Warrant.

\section{Social science}

A number of public awareness surveys have been undertaken in relation to the Treasure Islands campaign. Most recently 597 ferry passengers were surveyed in 2012. Seventy percent of surveyed ferry users said they had checked their gear, vehicle or 


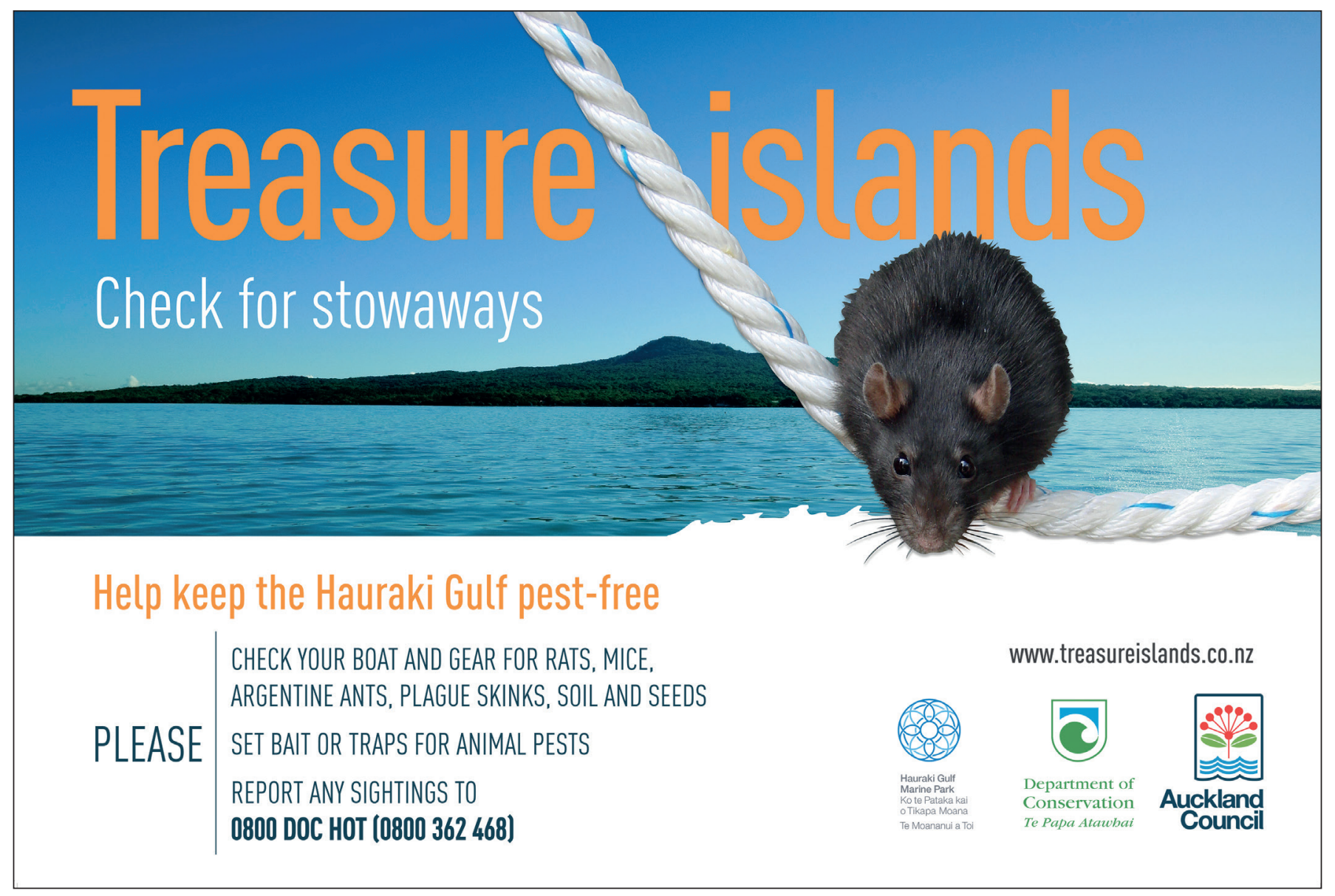

Figure 2: Example of Treasure Island signage.

vessel for pests (Tyrrell et al. 2012), although the survey does not elucidate the issue of how consistently respondents checked their gear. In addition, such surveys are likely to suffer from a level of self-reporting bias, as respondents may strive to present their behaviour in a socially desirable light (Podsakoff et al. 2003). Tāmaki Makaurau-Auckland residents appeared to have higher levels of understanding of island biosecurity issues than did respondents from outside the region, suggesting successful impact of repeated exposure to the Treasure Islands message (Tyrrell et al. 2012). The apparently high public willingness to take protective action is encouraging, given the potential difficulties associated with this type of messaging. However, there are a number of constraints on the inferences which can be drawn from this and previous survey work.

While the Treasure Islands campaign enjoys a positive public image (Tyrrell et al. 2012), there are a number of knowledge gaps relating to assessment of the campaign's success, several of which are weaknesses likely to be shared with many other comparable pro-environmental behaviour change programmes. While surveys to date suggest relatively high levels of positive behaviours amongst island visitors (e.g. Tyrrell et al. 2012), the absence of pre-Treasure Islands survey data makes it difficult to confidently draw a direct linkage between the Treasure Islands campaign and current behaviour patterns. Indeed, while desirable behaviours may be reasonably widely occurring, awareness of the campaign itself appears to be low, with only $23 \%$ of respondents aware of it (Tyrrell et al. 2012). Furthermore, there has been considerable variation in the design of surveys conducted since the inception of the campaign, further limiting any ability to track changes in behaviour over time. Future biosecurity public awareness campaigns should incorporate robustly designed social science prior to campaign initiation, with consistency of implementation throughout the duration of the programme to facilitate meaningful assessment of programmes' contributions to awareness and behaviour change over time.

Public surveys associated with Treasure Islands have typically focussed on awareness of pest issues and self-reported behaviour. In contrast, these surveys have not tended to investigate the 'barriers' which may prevent positive behaviour change. This is despite social marketing theory which suggests that identification and removal of barriers is a critical component of successfully converting environmental awareness into positive behaviour change (e.g. McKenzie-Mohr 2000). This highlights the often under-utilised potential of social science theoretical literature in informing survey work to better support the implementation of biosecurity programmes.

Measuring changes in public awareness, or even behaviour, is a form of operational monitoring. Ideally we would be able to assess changes in rates of human-mediated incursions to determine the efficacy of public awareness campaigns i.e. outcome monitoring. In the case of Treasure Islands, the public awareness campaign has been concurrent with on-going eradications within the HGMP. Therefore across the HGMP as a whole, incursion detection rates have been confounded by changes in mammal-free status and concomitant monitoring effort, along with the pre-eradication problem of detecting incursions on islands with extant populations of the invading 
pest. Not only is reliable data on pre-eradication incursions difficult to obtain, but we also lack data on pre-Treasure Islands incursions (i.e.pre-2000) onto pest-free islands, although these were generally fewer given the much lower number of pest-free islands at that time. Public awareness campaigns elsewhere that are initiated some time after pest eradication programmes might be more amenable to such outcome monitoring, as they would allow for gathering data on incursion rates in the absence of pests both before and after the initiation of the public awareness campaign. However, in areas with high human usage public awareness is likely a crucial component of successful island biosecurity and cannot be delayed to facilitate outcome monitoring. Advances in invasion biology may also go some way to addressing these sorts of issues, as we improve our understanding of pest behaviour and ability to measure or model invasion rates and sources prior to eradication (Bagasra et al. 2016).

\section{Future directions}

\section{Shifting taxonomic focus}

Introduced mammals have typically been the most widely recognised pest taxa in Aotearoa-New Zealand (Russell 2014). The relatively long history of rodent eradications on HGMP islands reflects this, as does the 'pest-free' status applied to HGMP islands following introduced mammal eradications, even when substantial weed and other pest issues may remain. While vertebrate pests benefited from the efforts of early acclimatisation societies, the taxonomic make up of contemporary and emerging invasions is shifting towards plants, invertebrates and pathogens. The HGMP islands are vulnerable to weed invasion through both bird and wind dispersal. In addition to natural dispersal pathways, many weed species have been beneficiaries of increased frequency of human movement, both domestic and international. Weed seeds are adept at hitchhiking into natural areas on footwear and clothing (Mount \& Pickering 2009; Pickering et al. 2011; Ansong \& Pickering 2013, 2014). Moreover, many of the HGMP Islands have resident human populations, and associated gardens and farms represent a high-risk source of potential weeds. Thus many HGMP islands are sources of weeds as well as recipients.

Other small cryptic taxa such as invertebrates and pathogens are benefiting from increases in the frequency and speed of human, goods and vehicle movements (e.g. Ward et al. 2005, 2006; Pickering et al. 2007; Pickering \& Hill 2007; Hughes et al. 2010; McNeil et al. 2011; Hulme 2014). The HGMP Islands are not immune to this trend. A survey of businesses in the Rodney district (mainland Auckland) found a high incidence of plague skinks and Argentine ants (Linepithema humile), often on or in goods destined for HGMP islands (Morgan et al. 2014). Highest risk businesses were service-based including holiday parks, yacht clubs and marinas, along with nurseries and construction businesses. While latest survey work indicates that kauri dieback disease is absent from HGMP Islands (with the exception of the longstanding infection on Aotea/Great Barrier), the presence of the disease in the wider Tāmaki Makaurau-Auckland region poses an on-going threat to island kauri forests.

\section{Multi-species vector control}

Given the taxonomically diverse array of pest species transported by humans to off-shore islands, multi-species management is vital. The recently released National Policy Direction for Pest Management will provide a new legislative tool for regional councils/unitary authorities to manage pathways: Pathway Management Plans. Unlike the traditional pest-led approach mandated for Regional Pest Management Strategies (now Plans), Pathway Management Plans will facilitate a vector-led approach, which may prove useful to Regional Councils in simultaneously addressing multi-species pest spread to off-shore islands.

In addition to potential legislative tools, vector control to islands will necessarily remain heavily dependent on public awareness and behaviour change. A key challenge will be in successfully communicating the broader, multi-species message to the public. A recent analysis of public attitudes to pest animals found possums, rats and mustelids collectively accounted for around one quarter of respondents' allocation of a hypothetical $\$ 100$ tax spend on animal pest control (Russell 2014). This high awareness of mammalian predators' impacts is perhaps not surprising given the high profile of these pests in the media (e.g. the 2014 Battle for Our Birds) and other public fora. For instance, $50 \%$ of the Aotearoa-New Zealand eco-tourism operations surveyed by Highham \& Carr (2002) provided visitor education and interpretation material addressing predator management and eradication. While this profile for rodents and other predators is laudable, the 'what you can do to help' message must encompass multi-species solutions which extend to cryptic taxa. While the Treasure Islands campaign had a rodent and ant focus at its inception, it has broadened to a more taxonomically inclusive, yet still succinct, list of pests to look out for.

\section{Pest management on inhabited islands}

Another difficult yet exciting challenge is the management of pests on islands with substantial resident human populations. In the five decades since Norway rats were eradicated from Ruapuke/Maria Island, the size of islands for which mammal eradication is technically feasible has increased vastly and is now beyond 10,000 ha (McClelland 2011). Thus the large inhabited Hauraki Gulf islands Waiheke (9,200 ha) and Aotea/ Great Barrier Island (28,500 ha) are now potential candidates for mammal eradication(Ogden \& Gilbert 2011) and lynchpins for biosecurity in the wider HGMP. Waiheke and Aotea/ Great Barrier Island are currently the source populations for reinvasion of neighbouring mammal-free islands by rodents (both Aotea/Great Barrier Island and Waiheke) and mustelids (Waiheke only). Ponui in the southern HGMP is another important island for which to secure mammal-free status. By way of comparison, successful eradication of cats and rats from Ahuahu/Great Mercury Island will finally secure the mammalfree status of the Mercury Islands (Towns et al. 2016). However, eradications on inhabited islands will not be achieved without wide-reaching support from island communities (Glen et al. 2013). Social barriers to eradication include concerns over toxin use, impacts on residents' lifestyles (e.g. implications for companion animals) and the dual values of both pest and resource which apply to some species (e.g. feral pigs, cats).

Vertebrate pest eradications are not the only biosecurity challenge facing island residents and their mainland neighbours. The distribution of human settlements and the species composition of garden plantings are powerful explanatory factors in the distribution of weeds in natural areas (Sullivan et al. 2004, 2005). Forest fragments within urban/rural developed landscapes on HGMP Islands already contain among the 
highest proportions of exotic plant species of all Tāmaki Makaurau-Auckland's forested areas (Lockie et al. 2013). Given that plant naturalisations lag half a century behind housing developments (Sullivan et al . 2004), today's gardening practices in and around the HGMP will affect the islands for many years to come. In the presence of a wide range of pests, both plant and animal, biosecurity on large inhabited islands must take a planned, multi-species approach, and incorporate monitoring and adaptive management to allow flexibility in the face of unexpected outcomes (Griffiths 2011; Glen et al. 2013). Again, social science has a key role in understanding motivations and diverse viewpoints to achieve successful island biosecurity at the scale of large inhabited islands.

\section{Conclusions}

Island biosecurity in the HGMP has undergone enormous advances in the five decades since the eradication of rats from Ruapuke/Maria Island. Eradication of mammals from islands in the HGMP has restored mammal pest-free status to around 16 islands/island groups, i.e. over half of those in the Hauraki Gulf. Successful island biosecurity programmes have maintained this mammal-free status in the face of ongoing rodent and mustelid incursions, by both boats and swimming. Biosecurity programmes have broadened from the single species Norway rat eradication of Ruapuke/Maria Island, to addressing a diverse range of invasive taxa, necessitating a multi-species focus on movement vectors. In light of the substantial role of humanmediated dispersal, managing public awareness and behaviour change has been an important component of biosecurity in the HGMP. The Treasure Islands public awareness campaign deserves recognition for its cohesive approach to supporting multi-species biosecurity programmes implemented by multiple agencies/individuals across multiple land ownership categories. Nonetheless, this programme also offers valuable insights for improvement, particularly in the use of robust social science to inform and monitor similar biosecurity-related public awareness and behaviour change programmes. In addition, conservation management and biosecurity must include large inhabited islands, which are critical for conservation within HGMP not only in their own right, but also because of their role as on-going sources of reinvasion for other mammal-free islands. Social science will again be critical in understanding and reconciling diverse viewpoints to yield further conservation gains within the HGMP.

\section{Acknowledgements}

The authors thank Sandra Sweeting (née Jack) and two anonymous reviewers for comments which substantially improved the quality of this manuscript, and Rob Chappell, Richard Griffiths, Mel Galbraith, Mike Lee, Mark Mitchell, Jo Ritchie, Andrew Veale and Karen Vincent for their help with data for the appendices. Thanks also to Shanti Morgan and Lydia Tyrrell for their unpublished surveys, and to Tim Higham (Hauraki Gulf Forum) for permission to reproduce the map in Figure 1.

\section{References}

Ansong M, Pickering C 2013. Long-distance dispersal of Black Spear Grass (Heteropogon contortus) seed on socks and trouser legs by walkers in Kakadu National Park. Ecological Management and Restoration 14:71-74.

Ansong M, Pickering C 2014. Weed seeds on clothing: a global review. Journal of Environmental Management 144: 203-211.

Atkinson IAE 1973. Protection and use of the islands in Hauraki Gulf Maritime Park. New Zealand Journal of Ecology 20: 103-114.

Bagasra A, Nathan HW, Mitchell MS, Russell JC 2016. Tracking invasive rat movements with a systemic biomarker. New Zealand Journal of Ecology 40: 267-272.

Bamberg S, Moser G 2007. Twenty years after Hines, Hungerford, and Tomera: a new meta-analysis of psychosocial determinants of pro-environmental behaviour. Journal of Environmental Psychology 27: 14-25.

Barbera M 2012. Towards an economic valuation of the Hauraki Gulf: a stock-take of activities and opportunities. Auckland Council technical report TR2012/035.Auckland, Auckland Council. 125 p.

Census Auckland 2015. Auckland Council. www. censusauckland.co.nz/census-area-unit-view/.

Clout MN, Russell JC 2008. The invasion ecology of mammals: a global perspective. Wildlife Research 35: 180-184.

Diamond JM, Veitch CR 1981. Extinctions and introductions in the New Zealand avifauna: cause and effect? Science 211: 499-501.

Dowding JE, O'Connor SM 2013. Reducing the risk of extinction of a globally threatened shorebird: translocations of the shore plover (Thinornis novaeseelandiae), 19902012. Notornis 60: 70-84.

Fewster RM, Miller SD, Ritchie J 2011. DNA profiling-a management tool for rat eradication. In: Veitch CR, Clout MN, Towns DR eds Island invasives: eradication and management. Gland, Switzerland, IUCN. Pp. 426-431.

Fransson N, Garling T 1999. Environmental concern: conceptual definitions, measurement methods, and research findings. Journal of Environmental Pysychology 19: 369-382.

Galbraith M 2013. Public and ecology - the role of volunteers on Tiritiri Matangi Island. New Zealand Journal of Ecology 37: 266-271.

Gaskin CP, Rayner MJ 2013. Seabirds of the Hauraki Gulf: natural history, research and conservation. Hauraki Gulf Forum. 143 p.

Gattig A, Hendrickx L 2007. Judgemental discounting and environmental risk perception: dimensional similarities, domain differences, and implications for sustainability. Journal of Social Issues 63: 21-39.

Glen AS, Atkinson R, Campbell KJ, Hagen E, Holmes ND, Keitt BS, Parkes JP, Saunders A, Sawyer J, Torres H 2013. Eradicating multiple invasive species on inhabited islands: the next big step in island restoration? Biological Invasions 15: 2589-2603.

Griffiths R 2011. Targeting multiple species - a more efficient approach to pest eradication. In: Veitch CR, Clout MN, Towns DR eds Island invasives: eradication and management. Gland, Switzerland, IUCN. Pp. 172-176.

Griffiths R, Buchanan F, Broome K, Neilsen J, Brown D, Weakley M 2015. Successful eradication of invasive vertebrates on Rangitoto and Motutapu Islands, New 
Zealand. Biological Invasions 17: 1355-1369.

Gsell A, Innes J, de Monchy P, Brunton D 2010. The success of using trained dogs to locate sparse rodents in pest-free sanctuaries. Wildlife Research 37: 39-46.

Gsell AC, Seabrook-Davison MNH, Brunton DH 2014. Are wild rodents attracted to lure laboratory rats? Pacific Conservation Biology 20: 108-115.

Hauraki Gulf Forum 2014. State of Our Gulf 2014: Hauraki Gulf -Tīkapa Moana/Te Moananui a Toi-State of the Environment Report 2014.Auckland, Hauraki GulfForum, Auckland Council. 195 p.

Highham J, Carr A 2002. Ecotourism visitor experiences in Aotearoa/New Zealand: challenging the environmental values of visitors in pursuit of pro-environmental behaviour. Journal of Sustainable Tourism 10: 277-294.

Hughes KA, Convey P, Maslen NR, Smith RIL 2010. Accidental transfer of non-native soil organisms into Antarctica on construction vehicles. Biological Invasions 12: 875-891.

Hulme P 2014. Invasive species challenge the global response to emerging diseases. Trends in Parasitology 30: 267-270.

Ismar SMH, Baird KA, Gaskin CP, Taylor GA, Tennyson AJD, Rayner MJ, Bettesworth D, Fitzgerald N, Landers TJ, Imber MJ 2014. A case of natural recovery after the removal of invasive predators-community assemblage changes in the avifauna of Burgess Island. Notornis 61: 188-195.

Kalamas M, Cleveland M, Laroche M2014. Pro-environmental behaviors for thee but not for me: green giants, greed Gods, and external environmental locus of control. Journal of Business Research 67: 12-22.

King CM, Veale A, Patty B, Hayward L 2014. Swimming capabilities of stoats and the threat to inshore sanctuaries. Biological Invasions 16: 987-995.

Lambert DM, King T, Shepherd LD, Livingston A, Anderson S, Craig JL 2005. Serial population bottlenecks and genetic variation: translocated populations of the New Zealand saddleback(Philesturnus carunculatus rufusater). Conservation Genetics 6: 1-14.

Lee M 1999. Biota of seven islets off Waiheke Island, Inner Hauraki Gulf. Tane 37: 99-136.

Lockie S, Bishop C, Landers T, Khin J 2013. Monitoring and reporting biodiversity change in rural habitat fragments across the Auckland region. Oral paper presented to ECOTAS Conference, Auckland 24-29 November 2013.

MacKay JWB 2011. Improving the success of mouse eradication attempts on islands. PhD thesis. Auckland, University of Auckland. 119 p.

McClelland PJ 2011. Campbell Island-pushing the boundaries of rat eradications. In: Veitch CR, Clout MN, Towns DR eds Island invasives: eradication and management. Gland, Switzerland, IUCN (International Union for Conservation of Nature). Pp. 204-207.

McKenzie-Mohr D 2000. Promoting sustainable behaviour: an introduction to community-based social marketing. Journal of Social Issues 56: 543-554.

McNeil M, Phillips C, Young S, Shah F, Aalders L, Bell N, Gerard E, Littlejohn R 2011. Transportation of nonindigenous species via soil on international aircraft passengers' footwear. Biological Invasions 13:2799-2815.

Morgan S, Marshall A, Cook J, Ward D, Galbraith M, Fraser D 2014. Risk pathways of Argentine ants (Linepithema humile) and the plague skink (Lapropholis delicata) from Rodney district businesses to the islands of the Hauraki Gulf. Paper presented to the New Zealand Ecological
Society Conference, Palmerston North 16-19 November 2014.

Mount A, Pickering CM 2009. Testing the capacity of clothing to act as a vector for non-native seed in protected areas. Journal of Environmental Management 91: 168-179.

Nathan HW, Clout MN, MacKay JWB, Murphy EC, Russell JC 2015. Experimental island invasion of house mice. Population Ecology 57: 363-371.

Nathan HW, Clout MN, Murphy EC, MacKay JW 2013. Strategies for detection of house mice on a recently invaded island. New Zealand Journal of Ecology 37: 26-32.

Ogden J, Gilbert J 2011. Running the gauntlet: advocating rat and feral cat eradication on an inhabited island Great Barrier Island, New Zealand. In: Veitch CR, Clout $\mathrm{MN}$, Towns DR eds Island invasives: eradication and management. Gland, Switzerland, IUCN (International Union for Conservation of Nature). Pp. 467-471.

Pickering CM, Hill W 2007. Impacts of recreation and tourism on plant biodiversity and vegetation in protected areas in Australia. Journal of Environmental Management 85: 791-800.

Pickering CM, Bear R, Hill W 2007. Indirect impacts of nature based tourism and recreation: the association between infrastructure and the diversity of exotic plants in Kosciuszko National Park, Australia. Journal of Ecotourism 6: 146-157.

Pickering CM, Mount A, Wichmann MC, Bullock JM 2011. Estimating human-mediated dispersal of seeds within an Australian protected area. Biological Invasions 13: 1869-1880.

Podsakoff PM, MacKenzie SB, Lee J-Y 2003. Common method biases in behavioural research: a critical review of the literature and recommended remedies. Journal of Applied Psychology 88: 879-903.

Ports of Auckland Limited 2015. Ports of Auckland. www. poal.co.nz. (accessed 20 January 2015).

Reaser JK, Meyerson LA, Cronk Q, De Poorter M, Eldrege LG 2007. Ecological and socioeconomic impacts of invasive alien species in island ecosystems. Environmental Conservation 34: 1-14.

Reaser JK, Meyerson LA, Von Holle B 2008. Saving camels from straws: how propagule pressure-based prevention policies can reduce the risk of biological invasion. Biological Invasions 10: 1085-1098.

Russell JC 2007. Invasion ecology and genetics of Norway rats on New Zealand islands. PhD thesis. Auckland, University of Auckland. 225 p.

Russell JC 2014. Acomparison of attitudes towards introduced wildlife in New Zealand in 1994 and 2012. Journal of the Royal Society of New Zealand 44: 136-151.

Russell JC, Beaven BM, MacKay JW, Towns DR, Clout MN 2008a. Testing island biosecurity systems for invasive rats. Wildlife Research 35: 215-221.

Russell JC, Broome KG 2016. Fifty years of rodent eradications in New Zealand: another decade of advances. New Zealand Journal of Ecology 40: 197-204.

Russell JC, Clout MN, McArdle BH 2004. Island biogeography and the species richness of introduced mammals on New Zealand offshore islands. Journal of Biogeography 31: 653-664.

Russell JC, Innes JG, Brown PH, Byrom AE 2015. PredatorFree New Zealand: conservation country. BioScience 65: 520-525.

Russell JC, McMorland AJ, MacKay JW 2010. Exploratory 
behaviour of colonizing rats in novel environments. Animal Behaviour 79: 159-164.

Russell JC, Towns DR, Clout MN 2008b. Review of rat invasion biology: implications for island biosecurity. Science for Conservation 286. Wellington, Department of Conservation. $53 \mathrm{p}$.

Ryan RL, Kaplan R, Grese RE 2001. Predicting volunteer commitment in environmental stewardship programmes. Journal of Environmental Planning and Management 44: 629-648.

Shapira I2014. Using social attraction to enhance trappability of invasive Norway rats (Rattus norvegicus). DOC Research and Development Series 342. Wellington, Department of Conservation. $13 \mathrm{p}$.

Shapira I, Shanas U, Raubenheimer D, Knapp C, Alberts S, Brunton D 2013. Laboratory rats as conspecific biocontrol agents for invasive Norway rats $R$. norvegicus. Biological Control 66: 83-91.

Sullivan JT, Timmins SM, Williams PA 2005. Movement of exotic plants into coastal native forests from gardens in northern New Zealand. New Zealand Journal of Ecology 29: $1-10$.

Sullivan JT, Williams PA, Cameron EK, Timmins SM 2004. People and time explain the distribution of naturalised plants in New Zealand. Weed Technology 18: 1330-1333.

Sweetapple P, Nugent G 2011. Chew-track-cards: a multiplespecies small mammal detection device. New Zealand Journal of Ecology 35: 153-162.
Towns DR, Borrelle SB, Thoresen J, Buxton RT, Evans A2016. Mercury Islands and their role in understanding seabird island restoration. New Zealand Journal of Ecology 40: 235-249.

Tyrrell L, Fraser D, Cook J, Waipara N, Edwards L 2012. Hauraki Gulf island biosecurity survey. Unpublished report to Auckland Council.

Veale AJ, Clout MN, Gleeson DM 2012. Genetic population assignment reveals a long-distance incursion to an island by a stoat (Mustela erminea). Biological Invasions 14: 735-742.

Ward DF, Beggs JR, Clout MN, Harris RJ, O’Connor S 2006. The diversity and origin of exotic ants arriving in New Zealand via human-mediated dispersal. Diversity and Distributions 12: 601-609.

Ward DF, Harris RJ, Stanely MC 2005. Human-mediated range expansion of Argentine ants Linepithema humile (Hymenoptera:Formicidae) in New Zealand. Sociobiology 45: 1-7.

Weir BS, Paderes EP, Anand N, Uchida JY, Pennycook SR, Bellgard SE, Beever RE 2015. A taxonomic revision of Phytophthora Clade 5 including two new species, Phytophthora agathidicida and P. cocois. Phytotaxa 205: 21-38. 
Appendix A: Eradications and Incursions of Mammals on Hauraki Gulf Islands

Table 1. Operations which have resulted in the successful eradication of an introduced mammal species from an island in the Hauraki Gulf. Methods listed are: $\mathrm{P}=$ poison; $\mathrm{T}=\operatorname{trap} ; \mathrm{S}=$ shooting; $\mathrm{D}=\operatorname{dog}$. * $=$ date confirmed after a 2 year confirmation process. $\dagger=$ ongoing programme due to high reinvasion risk.

\begin{tabular}{|c|c|c|c|c|c|c|c|}
\hline Location & Area & $\begin{array}{l}\text { Date } \\
\text { Introduced }\end{array}$ & $\begin{array}{l}\text { Eradication } \\
\text { Leader }\end{array}$ & $\begin{array}{l}\text { Date } \\
\text { Started }\end{array}$ & Methods & $\begin{array}{l}\text { Date } \\
\text { Completed }\end{array}$ & Reference \\
\hline \multicolumn{8}{|c|}{ HOUSE MOUSE Mus musculus } \\
\hline Karamuramu/Quarry & 7.5 & $?$ & J. McCallum & 2009 & $\mathrm{P}$ & 2013 & J. McCallum pers. comm. \\
\hline Mahuki & 45 & $?$ & J. Ritchie & 2009 & $\mathrm{P}$ & 2011 & Fewster et al. 2011 \\
\hline Motukorea/Browns & 58 & ? & C. R. Veitch & 1995 & $\mathrm{P}$ & $1997 *$ & Veitch 2002a \\
\hline Motuihe & 179 & $>1987$ & C. R. Veitch & 1997 & $\mathrm{P}$ & $1999 *$ & Veitch $2002 b$ \\
\hline Motutapu & 1560 & $?$ & R. Griffiths & 2009 & $\mathrm{P}$ & $2011 *$ & Griffiths et al. 2015 \\
\hline Ohīnau & 46 & $?$ & R. Chappell & 2005 & $\mathrm{P}$ & $2007 *$ & Chappell 2008 \\
\hline Papakōhatu/Crusoe & 0.7 & $1949 ?$ & M. Lee & 1996 & $\mathrm{P}, \mathrm{T}$ & 1997 & Lee 1999 \\
\hline Rangitoto & 2321 & $?$ & R. Griffiths & 2009 & $\mathrm{P}$ & $2011 *$ & Griffiths et al. 2015 \\
\hline Rotoroa & 90 & $<2000$ & J. Ritchie & 2013 & $\mathrm{P}$ & $2015^{*}$ & J. Ritchie pers. comm. \\
\hline Te Haupa/Saddle & 6 & 2009 & H. Nathan & 2010 & $\mathrm{P}, \mathrm{T}$ & 2010 & Nathan et al. 2015 \\
\hline Whenuakura (Whangamata) & 2 & c1980 & I. McFadden & 1983 & $\mathrm{P}$ & 1984 & Newman 1985 \\
\hline \multicolumn{8}{|l|}{ PACIFIC RAT Rattus exulans } \\
\hline Arch & 1 & $?$ & I. McFadden & 1990 & $\mathrm{P}$ & 1991 & McFadden 1992b \\
\hline Burgess & 56 & ? & I. McFadden & 1990 & $\mathrm{P}$ & 1991 & McFadden \& Greene 1994 \\
\hline Cuvier & 170 & $<1827$ & P. Thomson & 1993 & $\mathrm{P}$ & $1995^{*}$ & Towns et al. 1995 \\
\hline Double & 27 & c1900 & I. McFadden & 1989 & $\mathrm{P}$ & 1989 & McFadden 1992a \\
\hline Fanal & 73 & ? & C. R. Veitch & 1997 & $\mathrm{P}$ & $1999 *$ & Veitch 2002c \\
\hline Flax & 1 & $?$ & I. McFadden & 1990 & $\mathrm{P}$ & 1991 & McFadden \& Greene 1994 \\
\hline Hauturu-O-Toi/Little Barrier & 3083 & $?$ & R. Griffiths & 2004 & $\mathrm{P}$ & $2006^{*}$ & Campbell 2011 \\
\hline Korapuki & 18 & c1900 & I. McFadden & 1986 & $\mathrm{P}$ & 1987 & McFadden \& Towns 1991 \\
\hline Lizard & 1 & 1977 & C. R. Veitch & 1978 & $\mathrm{P}$ & 1978 & McCallum 1986 \\
\hline Maori Bay & 11 & $?$ & I. McFadden & 1990 & $\mathrm{P}$ & 1991 & McFadden \& Greene 1994 \\
\hline Middle Chain & 23 & $?$ & R. Thorpe & 1992 & $\mathrm{P}$ & $1994 *$ & Thorpe 1997 \\
\hline Motupapa 'Stack C' & 2 & $?$ & I. McFadden & 1990 & $\mathrm{P}$ & 1991 & McFadden \& Greene 1994 \\
\hline Motutapu & 1560 & ? & R. Griffiths & 2009 & $\mathrm{P}$ & $2011 *$ & Griffiths et al. 2015 \\
\hline Ohīnau & 46 & $?$ & R. Chappell & 2005 & $\mathrm{P}$ & $2007 *$ & Chappell 2008 \\
\hline Rangitoto & 2321 & $?$ & R. Griffiths & 2009 & $\mathrm{P}$ & $2011 *$ & Griffiths et al. 2015 \\
\hline Red Mercury & 225 & ? & P. Thomson & 1992 & $\mathrm{P}$ & 1994* & Towns et al. 1994 \\
\hline Stacks B-G,I,J & 10 & $?$ & I. McFadden & 1990 & $\mathrm{P}$ & 1991 & McFadden \& Greene 1994 \\
\hline Stanley & 100 & $<1900$ & I. McFadden & 1991 & $\mathrm{P}$ & 1992 & Towns et al. 1993 \\
\hline Tiritiri Matangi & 196 & $?$ & C. R. Veitch & 1993 & $\mathrm{P}$ & $1995^{*}$ & Veitch 2002d \\
\hline Trig & 16 & $?$ & I. McFadden & 1990 & $\mathrm{P}$ & 1991 & McFadden \& Greene 1994 \\
\hline \multicolumn{8}{|l|}{ SHIP RAT Rattus rattus } \\
\hline Papakurī & 0.5 & $?$ & J. Ritchie & 2009 & $\mathrm{P}$ & $2011 * \dagger$ & Fewster et al. 2011 \\
\hline Nelson & 13 & ? & J. Ritchie & 2008 & $\mathrm{P}$ & $2010 * \dagger$ & Fewster et al. 2011 \\
\hline Moturako & 4 & $?$ & J. Ritchie & 2008 & $\mathrm{P}$ & $2010 * \dagger$ & Fewster et al. 2011 \\
\hline Sugarloaf & 3 & $?$ & J. Ritchie & 2008 & $\mathrm{P}$ & $2010^{*} \dagger$ & Fewster et al. 2011 \\
\hline Motutapere & 45 & 2003 & R. Chappell & 2005 & $\mathrm{P}$ & $2007 *$ & Chappell 2008 \\
\hline Motutapu & 1560 & $?$ & R. Griffiths & 2009 & $\mathrm{P}$ & $2011 *$ & Griffiths et al. 2015 \\
\hline Rangitoto & 2321 & $?$ & R. Griffiths & 2009 & $\mathrm{P}$ & $2011 *$ & Griffiths et al. 2015 \\
\hline Ruthe Islet & 0.6 & $<2013$ & M. Lee & 2013 & $\mathrm{P}$ & 2014 & M. Lee pers. comm. \\
\hline \multicolumn{8}{|c|}{ NORWAY RAT Rattus norvegicus } \\
\hline David Rocks & 1 & 1960 & D. Merton & 1960 & $\mathrm{P}$ & 1964 & Moors $1985 \mathrm{a}$ \\
\hline Hauturu (Whangamata) & 10 & c1972 & P. Thomson & 1992 & $\mathrm{P}$ & $1994 *$ & Glassey 2004 \\
\hline Karamuramu/Quarry & 7.5 & $?$ & J. McCallum & 2009 & $\mathrm{P}$ & 2009 & J. McCallum pers. comm. \\
\hline Koi & 0.28 & 2000 & M. Lee & 2000 & $\mathrm{P}$ & 2000 & M. Lee pers. comm. \\
\hline Motuhoropapa & 9 & 2002 & G. Wilson & 2002 & $\mathrm{P}$ & 2002 & Wilson 2003 \\
\hline Motuihe & 179 & 1997 & C. R. Veitch & 1997 & $\mathrm{P}$ & $1999 *$ & Veitch 2002b \\
\hline Motukorea/Browns & 58 & $1980 \mathrm{~s}$ & C. R. Veitch & 1995 & $\mathrm{P}$ & 2000 & Veitch $2002 \mathrm{a}$ \\
\hline Otata & 22 & 2002 & G. Wilson & 2002 & $\mathrm{P}$ & 2002 & Wilson 2003 \\
\hline Pakatoa & 29 & 2012 & N. Atkins & 2012 & $\mathrm{P}$ & 2014 & K. Giles pers. comm. \\
\hline Rakino & 148 & $1920-72$ & $\begin{array}{l}\text { Hix, Waters, } \\
\text { Wilson }\end{array}$ & 2002 & $\mathrm{P}$ & $2004 *$ & J. MacKenzie pers. comr \\
\hline Rotoroa & 90 & c1999 & J. Ritchie & 2010 & $\mathrm{P}$ & $2012 *$ & Russell et al. 2011 \\
\hline Ruapuke/Maria & 2 & 1959 & D. Merton & 1960 & $\mathrm{P}$ & 1964 & Moors 1985a \\
\hline Tarahiki/Shag & 5 & c1998 & G. Wilson & 2000 & $\mathrm{P}$ & $2002 *$ & G. Wilson pers. comm. \\
\hline Te Haupa/Saddle & 6 & $<1981$ & R. Gilfillan & 1989 & $\mathrm{P}$ & 1989 & Tennyson \& Taylor 1999 \\
\hline Whenuakura (Whangamata) & 2 & c1982 & McFadden, Wilke & 1983 & $\mathrm{P}$ & 1984 & Newman $1985^{\circ}$ \\
\hline
\end{tabular}




\begin{tabular}{|c|c|c|c|c|c|c|c|}
\hline Location & Area & $\begin{array}{l}\text { Date } \\
\text { Introduced }\end{array}$ & $\begin{array}{l}\text { Eradication } \\
\text { Leader }\end{array}$ & $\begin{array}{l}\text { Date } \\
\text { Started }\end{array}$ & Methods & $\begin{array}{l}\text { Date } \\
\text { Completed }\end{array}$ & Reference \\
\hline \multicolumn{8}{|l|}{ STOAT Mustela erminea } \\
\hline Moturuhi & 57 & ? & R. Chappell & 2002 & $\mathrm{~T}$ & 2003 & Veale et al. $2012 \mathrm{~b}$ \\
\hline Motutapere & 45 & $?$ & R. Chappell & 2004 & $\mathrm{~T}$ & 2004 & Veale et al. 2012b \\
\hline Motutapu & 1560 & $?$ & R. Griffiths & 2009 & $\mathrm{P}$ & 2009 & Griffiths et al. 2015 \\
\hline Pakihi/Sandspit & 114 & 2006 & J. McCallum & 2009 & $\mathrm{~T}$ & 2009 & J. McCallum pers. comm. \\
\hline Rangitoto & 2321 & $?$ & R. Griffiths & 2009 & $\mathrm{P}$ & 2009 & Griffiths et al. 2015 \\
\hline Waimate & 70 & $?$ & R. Chappell & 2005 & $\mathrm{~T}$ & 2005 & Veale et al. $2012 b$ \\
\hline \multicolumn{8}{|l|}{ GUINEA PIG Cavia porcellus } \\
\hline Motuketekete & 24 & $?$ & $?$ & $?$ & $\mathrm{D}$ & $?$ & J. Vivian pers. comm. \\
\hline \multicolumn{8}{|c|}{ HEDGEHOG Erinaceus europaeus } \\
\hline Motutapu & 1560 & $?$ & R. Griffiths & 2009 & $\mathrm{P}, \mathrm{T}, \mathrm{D}$ & 2011 & Griffiths et al. 2015 \\
\hline Rangitoto & 2321 & $?$ & R. Griffiths & 2009 & $\mathrm{P}$ & 2011 & Griffiths et al. 2015 \\
\hline \multicolumn{8}{|l|}{ RABBIT Oryctolagus cuniculus } \\
\hline Motukorea/Browns & 58 & $\mathrm{c} 1975$ & F. David & 1985 & $\mathrm{P}, \mathrm{T}, \mathrm{D}, \mathrm{S}$ & 1991 & Veitch $2002 \mathrm{a}$ \\
\hline Korapuki & 18 & c1900 & I. McFadden & 1986 & $\mathrm{P}, \mathrm{S}$ & 1988 & Towns 2002 \\
\hline Motuihe & 179 & $?$ & S. Mowbray & 2002 & $\mathrm{P}, \mathrm{S}$ & 2004 & $\begin{array}{l}\text { D. Thompson pers. } \\
\text { comm. }\end{array}$ \\
\hline Motutapu & 1560 & $?$ & R. Griffiths & 2009 & $\mathrm{P}, \mathrm{T}$ & 2010 & Griffiths et al. 2015 \\
\hline Otata & 15 & $?$ & $\begin{array}{l}\text { Captain } \\
\text { Wainhouse }\end{array}$ & $?$ & $\mathrm{~S}$ & 1945 & $\begin{array}{l}\text { B. Neureuter pers. } \\
\text { comm. }\end{array}$ \\
\hline Ohīnau & 46 & $?$ & R. Chappell & 2005 & $\mathrm{P}$ & 2007 & Chappell 2008 \\
\hline Rangitoto & 2321 & $?$ & R. Griffiths & 2009 & $\mathrm{P}$ & 2010 & Griffiths et al. 2015 \\
\hline Stanley & 100 & c1900 & I. McFadden & 1991 & $\mathrm{P}$ & 1992 & Towns et al. 1993 \\
\hline Tiritiri Matangi & 196 & $<1894$ & E. Hobbs & c1900 & $?$ & c1920 & Veitch 2002d \\
\hline \multicolumn{8}{|l|}{ CAT Felis catus } \\
\hline Cuvier & 170 & $\mathrm{c} 1889$ & D. Merton & 1960 & $\mathrm{~T}, \mathrm{~S}$ & 1964 & Merton 1970 \\
\hline Great Mercury/Ahuahu & 1872 & $?$ & P. Corson & 2014 & $\mathrm{P}, \mathrm{T}, \mathrm{D}, \mathrm{S}$ & 2015 & P. Corson pers. comm. \\
\hline Hauturu-O-Toi/Little Barrier & 3083 & $<1870$ & C. R. Veitch & 1977 & $\mathrm{P}, \mathrm{T}, \mathrm{D}$ & 1980 & Veitch 2001 \\
\hline Motuihe & 160 & $\mathrm{c} 1984$ & S. Mowbray & 2002 & $\mathrm{~T}, \mathrm{~S}$ & 2004 & D. Thompson pers. comm. \\
\hline Motutapu & 1560 & $?$ & R. Griffiths & 2009 & $\mathrm{P}, \mathrm{T}, \mathrm{S}$ & 2009 & Griffiths et al. 2015 \\
\hline Rangitoto & 2321 & $?$ & R. Griffiths & 2009 & $\mathrm{P}, \mathrm{T}, \mathrm{S}$ & 2009 & Griffiths et al. 2015 \\
\hline \multicolumn{8}{|c|}{ BRUSHTAIL POSSUM Trichosurus vulpecula } \\
\hline Motutapere & 45 & $<1970$ & P. Thomson & 1994 & $\mathrm{P}$ & 1996 & P. Thomson pers. comm. \\
\hline Motutapu & 1560 & 1868 & S. Mowbray & 1990 & $\mathrm{P}, \mathrm{T}, \mathrm{D}, \mathrm{S}$ & 1996 & Mowbray 2002 \\
\hline Rangitoto & 2321 & 1868 & S. Mowbray & 1990 & $\mathrm{P}, \mathrm{T}, \mathrm{D}, \mathrm{S}$ & 1996 & Mowbray 2002 \\
\hline \multicolumn{8}{|c|}{ BRUSH-TAILED ROCK WALLABY Petrogale penicillata } \\
\hline Motutapu & 1560 & 1873 & S. Mowbray & 1990 & $\mathrm{P}, \mathrm{T}, \mathrm{D}, \mathrm{S}$ & 1997 & Mowbray 2002 \\
\hline Rangitoto & 2321 & 1873 & S. Mowbray & 1990 & $\mathrm{P}, \mathrm{T}, \mathrm{D}, \mathrm{S}$ & 1997 & Mowbray 2002 \\
\hline $\begin{array}{l}\text { Aotea/Great Barrier } \\
\text { [part-Reef Point] }\end{array}$ & $?$ & 1980 & $\begin{array}{l}\text { A. Leigh, } \\
\text { K. Purdon }\end{array}$ & 1981 & $\mathrm{~T}$ & 1981 & $\begin{array}{l}\text { Eadie \& Broome } \\
1990\end{array}$ \\
\hline \multicolumn{8}{|l|}{ GOAT Capra hircus } \\
\hline Burgess & 56 & $?$ & C. R. Veitch & 1973 & $\mathrm{~S}$ & 1973 & Veitch 1973 \\
\hline Cuvier & 170 & $1890 \mathrm{~s}$ & B. Bell & 1959 & $\mathrm{~S}$ & 1961 & Merton 1970 \\
\hline Aotea/Great Barrier & 27761 & $<1841$ & NZFS/AC/DOC & 1986 & $\mathrm{~S}, \mathrm{D}$ & 2005 & GBI SOE 2010 \\
\hline Mahurangi & 23 & c1900 & $?$ & $?$ & $?$ & 1915 & Atkinson 1972 \\
\hline Moturekareka & 19 & $?$ & C. Hansen & $?$ & $\mathrm{~S}$ & $?$ & Tennyson et al. 1997 \\
\hline Rakitu/Arid & 328 & $?$ & D. Agnew & 2002 & $\mathrm{~S}$ & 2002 & Agnew 2002 \\
\hline \multicolumn{8}{|l|}{ PIG Sus scrofa } \\
\hline Moturuhi & 57 & $?$ & $?$ & $?$ & $?$ & $<1970$ & McIlroy 1990 \\
\hline Rakitu/Arid & 328 & $?$ & $?$ & $?$ & $?$ & $1960 \mathrm{~s}$ & McIlroy 1990 \\
\hline \multicolumn{8}{|l|}{ DEER Dama dama } \\
\hline Kaikōura/Selwyn & 564 & 1930 & J. Ritchie & 2006 & $\mathrm{D}, \mathrm{S}$ & 2009 & Rowan 2013 \\
\hline Motutapu & 1560 & 1862 & F. David & 1929 & $\mathrm{~S}$ & 1990 & Julian 1992 \\
\hline Rangitoto & 2321 & $>1862$ & F. David & 1929 & $\mathrm{~S}$ & 1990 & Julian 1992 \\
\hline
\end{tabular}


Table 2. Operations which have not resulted in the eradication of an introduced mammal species from an island in the Hauraki Gulf. These operations are listed as: "incomplete" where the work is continuing or confirmation of the eradication has not been obtained; "stopped" where the work was stopped due to a management decision before the planned work was completed; "failed" where the planned programme was completed and eradication was not successful. Methods listed are: $\mathrm{P}=$ poison; $\mathrm{T}=$ trap; $\mathrm{S}=$ shooting; $\mathrm{D}=$ dogs.

\begin{tabular}{|c|c|c|c|c|c|c|}
\hline Location & Area & $\begin{array}{l}\text { Date } \\
\text { Introduced }\end{array}$ & $\begin{array}{l}\text { Eradication } \\
\text { Leader }\end{array}$ & $\begin{array}{l}\text { Date } \\
\text { Started }\end{array}$ & Methods & Reference \\
\hline
\end{tabular}

\section{INCOMPLETE}

HOUSE MOUSE Mus musculus

Motuketekete

Moturekareka

24

J. MacKay

K. Reynolds

2014

2014

PACIFIC RAT Rattus exulans

Ahuahu/Great Mercury

SHIP RAT Rattus rattus

Ahuahu/Great Mercury

Moturako

Opakau

Oyster

Saddle

Wood

Wood Stack A
P. Corson

2014

1872

1

4

1

2

1

\section{STOPPED}

NORWAY RAT Rattus norvegicus

Rakino

M. Lee

1997

P

M. Lee pers. comm.

RABBIT Oryctolagus cuniculus

Motuihe

Veitch 2002b

CAT Felis catus

Motuihe

C. R. Veitch

1997

P

Veitch 2002b

\section{UNSUCCESSFUL}

HOUSE MOUSE Mus musculus

Hauturu (Whangamata)

$10 \quad \mathrm{c} 1980$

Te Haupa/Saddle

?

P. Thomson

1994

1993

$\mathrm{P}$

$\mathrm{P}$

Glassey 2004

PACIFIC RAT Rattus exulans

Kaikōura/Selwyn

J. Ritchie

2008

P

Fewster et al. 2011

SHIP RAT Rattus rattus

Kaikōura/Selwyn

$564 ?$

J. Ritchie

2008

P

Fewster et al. 2011

NORWAY RAT Rattus norvegicus

Rakino

Rotoroa

MacKay 2014

s. comm.

G. Taylor pers. comm.

.

Taylor pers. comm.

G. Taylor pers. comm.

G. Taylor pers. comm. 
Table 3. Operations which resulted in the successful eradication of an introduced mammal species from an island in the Hauraki Gulf, but where the species re-invaded at a later date. Date completed is for the fieldwork component of the eradication. Methods listed are: $\mathrm{P}=$ poison; $\mathrm{T}=\operatorname{trap} ; \mathrm{S}=$ shooting; $\mathrm{D}=$ dogs. $\dagger=$ ongoing programme due to high reinvasion risk, $\wedge^{\wedge}=$ intentional reinvasion

\begin{tabular}{|c|c|c|c|c|c|c|}
\hline Location & Area & $\begin{array}{l}\text { Date } \\
\text { Introduced }\end{array}$ & $\begin{array}{l}\text { Eradication } \\
\text { Leader }\end{array}$ & $\begin{array}{l}\text { Date } \\
\text { Completed }\end{array}$ & Methods & $\begin{array}{l}\text { Date } \\
\text { re-invaded }\end{array}$ \\
\hline
\end{tabular}

\section{RE-INVASION}

HOUSE MOUSE Mus musculus

Te Haupa/Saddle

$6 ?$

SHIP RAT Rattus rattus

Goat

Goat

Grey Group

Koi

Little Mahuki

Mahuki

Motuhaku

Motutaiko

Motutapere

Rangiahua/Flat

J. MacKay 2008

$\mathrm{P}, \mathrm{T} \quad 2009^{\wedge}$

MacKay et al. 2011

Ruthe Islet

$\begin{array}{rl}9 & <1977 \\ 9 & 1996 \\ 4 & ? \\ 0.3 & ? \\ 2.5 & ? \\ 45 & ? \\ 43 & ? \\ 25 & ? \\ 45 & ? \\ 65 & ? \\ 0.6 & 1994\end{array}$

$\begin{array}{ll}\text { T. Wilson } & 1994 \\ \text { J. Russell } & 2005 \\ \text { J. Ritchie } & 2008 \\ \text { M. Lee } & 1997 \\ \text { J. Ritchie } & 2009 \\ \text { J. Ritchie } & 2009 \\ \text { J. Ritchie } & 2008 \\ \text { J. Ritchie } & 2009 \\ \text { P. Thomson } & 1996 \\ \text { J. Ritchie } & 2009 \\ \text { I. McFadden } & 1996\end{array}$

$\begin{array}{ll}\mathrm{P} & 1996 \\ \mathrm{P}, \mathrm{T} & 2007 \dagger \\ \mathrm{P} & 2010 \dagger \\ \mathrm{P}, \mathrm{T} & 2000 \$ 1 \\ \mathrm{P} & 2014 \dagger \\ \mathrm{P} & 2014 \dagger \\ \mathrm{P} & 2013 \dagger \\ \mathrm{P} & 2014 \dagger \\ \mathrm{P} & 2003 \\ \mathrm{P} & 2014 \dagger \\ \mathrm{P} & <2013\end{array}$

Russell et al. 2009

Russell et al. 2009

Fewster et al. 2011

Lee 1999

Fewster et al. 2011

Fewster et al. 2011

Fewster et al. 2011

Fewster et al. 2011

Chappell 2008

Fewster et al. 2011

Lee 1999

NORWAY RAT Rattus norvegicus

Karamuramu/Quarry

\section{J. McCallum 1999}

$\mathrm{P}$

2005

Motuhoropapa

Motuhoropapa

Motuhoropapa

Motuhoropapa

Motuhoropapa

Motuhoropapa

Motuihe

\section{G. Wilson 2001}

I. McFadden 1997

I. McFadden 1991

P. Moors 1984

P. Moors 1981

P. Moors 1978

$\begin{array}{ll}? & 1988\end{array}$

Otata

G. Wilson

2001

Otata

I. McFadden 1991

Otata

Otata

Pakatoa

P. Moors

1981

P. Moors 1979

M. Lee 1993

P 2005

J. Russell pers.

comm.

Wilson 2003

Cameron 1998

Cameron 1998

Moors 1985b

Moors 1985b, 1987

Moors 1981, 1985b

Veitch 2002b

Wilson 2003

Cameron 1998

Moors 1985b, 1987

Moors 1981, 1985b

M. Lee pers.

comm.

Pakatoa

$29 \quad 1997$

M. Lee

1998

M. Lee pers.

comm.

Rotoroa

90 ?

M. Lee

1997

M. Lee

1992

$\mathrm{P}$

c1999

Ruthe Islet

0.6 ?

$\mathrm{P}$

$1994^{\S 2}$

M. Lee pers.

comm.

de Lange \&

McFadden 1995

CAT Felis catus

Motuihe

$160 \quad \mathrm{c} 1800$

Steve Boyle 1981

S

c1984

Veitch 1985, 2002b

$\$ 1$ Reinvaded by Norway rats (Rattus norvegicus)

$\$ 2$ Reinvaded by ship rats (Rattus rattus) 
Table 4. Operations which have resulted in the successful interception of an introduced mammal species on an island in the Hauraki Gulf. Date is earliest record of detection. Methods listed are: $\mathrm{P}=$ poison; $\mathrm{T}=\operatorname{trap} ; \mathrm{D}=\mathrm{dogs} ; \mathrm{M}=\mathrm{monitoring}$ device (tunnel, waxtag or chew card); $\mathrm{R}=$ Delilah rats; $\mathrm{C}=$ camera; $\mathrm{S}=$ shooting. Excludes experimental incursions of rodents on islands and islands with high rates of incursion interception where 'eradication' is an ongoing programme. ? indicates unconfirmed.

\begin{tabular}{|c|c|c|c|c|c|c|}
\hline Location & $\mathbf{S p p} / \mathbf{S x}$ & Mode & Outcome & Date & Methods & Reference \\
\hline \multicolumn{7}{|c|}{ HOUSE MOUSE Mus musculus } \\
\hline Tiritiri Matangi & $\mathrm{Mm} / ?$ & boat & trapped on boat & $06-2006$ & $\mathrm{P}, \mathrm{T}$ & R. Renwick pers. comm. \\
\hline Te Haupa/Saddle & $\mathrm{Mm} / \mathrm{F}$ & boat & in eradication & $03-2010$ & $\mathrm{P}, \mathrm{T}$ & Nathan et al. 2015 \\
\hline Rangiahua/Flat & $\mathrm{Mm} / ?$ & boat & poisoned in house & $? ?-2011$ & $\mathrm{P}$ & H. Ngawaka pers. comm. \\
\hline \multicolumn{7}{|l|}{ SHIP RAT Rattus rattus } \\
\hline Halfmoon Bay Marina & $\mathrm{Rr} / \mathrm{F}$ & boat & caught by dog & 03-2011 & $\mathrm{P}, \mathrm{D}$ & P. Brown pers. comm. \\
\hline Rangitoto & $\mathrm{Rr} / \mathrm{F}$ & bird & dead on arrival & $03-2012$ & $\mathrm{P}, \mathrm{T}, \mathrm{M}$ & P. Brown pers. comm. \\
\hline \multicolumn{7}{|c|}{ NORWAY RAT Rattus norvegicus } \\
\hline Otata & $\mathrm{Rn} / \mathrm{M}$ & swim & trapped on island & 03-2005 & $\mathrm{P}, \mathrm{T}, \mathrm{D}, \mathrm{M}$ & Russell et al. 2005 \\
\hline Tiritiri Matangi & $\mathrm{Rn} / ?$ & boat & trapped on boat & $09-2007$ & $\mathrm{P}, \mathrm{T}$ & T. Wilson pers. comm. \\
\hline Motuora & $\mathrm{Rn} / \mathrm{M}$ & swim? & trapped & $02-2008$ & $\mathrm{P}, \mathrm{T}, \mathrm{D}, \mathrm{R}$ & T. Wilson pers. comm. \\
\hline Motuihe & $\mathrm{Rn} / \mathrm{F}$ & swim & caught by dog & 04-2008 & $\mathrm{P}, \mathrm{T}, \mathrm{D}, \mathrm{M}$ & P. Brown pers. comm. \\
\hline Te Haupa/Saddle & $\mathrm{Rn} / \mathrm{M}$ & swim & trapped & $03-2008$ & $\mathrm{~T}$ & MacKay 2011 \\
\hline Motuora & $\mathrm{Rn} / ?$ & swim & trapped & $02-2010$ & $\mathrm{P}, \mathrm{T}, \mathrm{M}$ & T. Wilson pers. comm. \\
\hline Motutapere & $\mathrm{Rn} / \mathrm{M}$ & swim & trapped & $05-2010$ & $\mathrm{~T}, \mathrm{D}$ & R. Chappell pers. comm. \\
\hline Rangitoto & $\mathrm{Rn} / \mathrm{F}$ & swim & presumed poisoned & $05-2011$ & $\mathrm{P}, \mathrm{T}, \mathrm{D}, \mathrm{M}, \mathrm{R}$ & F. Buchanan pers. comm. \\
\hline Tiritiri Matangi & $\mathrm{Rn} / ?$ & $?$ & dead on arrival & $02-2012$ & & T. Wilson pers. comm. \\
\hline Pakihi/Sandspit & $\mathrm{Rn} / ?$ & swim & trapped & 03-2012 & $\mathrm{T}$ & J. McCallum pers. comm. \\
\hline Pakihi/Sandspit & $\mathrm{Rn} / ?$ & swim & trapped & 07-2014 & $\mathrm{T}$ & J. McCallum pers. comm. \\
\hline Rotoroa & $\mathrm{Rn} / \mathrm{M}$ & swim & trapped & 04-2015 & $\mathrm{P}, \mathrm{T}, \mathrm{D}, \mathrm{M}$ & Ritchie 2015 \\
\hline \multicolumn{7}{|l|}{ STOAT Mustela erminea } \\
\hline Waimate & M & swim & trapped & $03-2006$ & $\mathrm{~T}$ & Veale et al. 2012b \\
\hline Waimate & M & swim & trapped & $11-2006$ & $\mathrm{~T}$ & Veale et al. $2012 b$ \\
\hline Motutapere & $?$ & swim & trapped & $09-2007$ & $\mathrm{~T}$ & Veale et al. $2012 \mathrm{~b}$ \\
\hline Waimate & M & swim & trapped & $09-2007$ & $\mathrm{~T}$ & Veale et al. 2012b \\
\hline Motutapere & $\mathrm{F}$ & swim & trapped & $12-2009$ & $\mathrm{~T}$ & Veale et al. $2012 b$ \\
\hline Moturuhi & M & swim & dead on arrival & $03-2010$ & $\mathrm{~T}$ & Veale et al. $2012 \mathrm{~b}$ \\
\hline Rangitoto & M & swim & trapped & $07-2010$ & $\mathrm{~T}$ & Veale et al. $2012 \mathrm{a}$ \\
\hline Motutapere & $\mathrm{F}$ & swim & trapped & $07-2012$ & $\mathrm{~T}$ & R. Chappell pers. comm. \\
\hline Motutapere & M & swim & trapped & $07-2013$ & $\mathrm{~T}$ & R. Chappell pers. comm. \\
\hline Motutapere & M & swim & trapped & $02-2014$ & $\mathrm{~T}$ & R. Chappell pers. comm. \\
\hline Motutapu & $\mathrm{F}$ & swim & trapped & $08-2014$ & $\mathrm{~T}$ & A. Veale pers. comm. \\
\hline \multicolumn{7}{|l|}{ FERRET Mustela furo } \\
\hline Aotea/Great Barrier & $?$ & boat & returned to boat & $08-2002$ & None & Veale 2013 \\
\hline Waiheke & $?$ & boat & observed on deck & $09-2007$ & $\mathrm{~T}$ & A. Spence pers. comm. \\
\hline \multicolumn{7}{|l|}{ OTTER Aonyx cinerea } \\
\hline Motutapu & $\mathrm{F}$ & swim & live captured & $06-2006$ & $\mathrm{~T}$ & J. Healy pers. comm. \\
\hline \multicolumn{7}{|c|}{ RABBIT Oryctolagus cuniculus } \\
\hline Motukorea/Browns & M? & boat & trapped and shot & $01-2015$ & $\mathrm{~T}, \mathrm{D}, \mathrm{S}$ & Nanning 2015 \\
\hline \multicolumn{7}{|c|}{ BRUSHTAIL POSSUM Trichosurus vulpecula } \\
\hline Waiheke & $?$ & boat & run-over & $04-2001$ & None & S. Hix pers. comm. \\
\hline Aotea/Great Barrier & M & boat & trapped on boat & $10-2010$ & $\mathrm{~T}$ & $\begin{array}{l}\text { Ramón-Laca \& Gleeson } \\
2014\end{array}$ \\
\hline
\end{tabular}




\section{References to Appendix A}

Agnew D 2002. Unpublished file notes on the eradication of goats from Rakitu (Arid) Island, Great Barrier. Great Barrier Island, Department of Conservation.

Atkinson IAE1972. Report on Mahurangi Island Mercury Bay. Unpublished report, Botany Division, DSIR.

Cameron E 1998. Bot Soc trips to the Noises (Hauraki Gulf) and an updated species list. Auckland Botanical Society Journal 53: 25-35.

CampbellDJ 2011. Seedling recovery on Hauturu/Little Barrier Island, after eradication of Pacific rats Rattus exulans. DOC Research \& Development Series 325. Wellington, Department of Conservation. $53 \mathrm{p}$.

Chappell R 2008. Operational plan for eradication of ship rats (Rattus rattus), kiore (Rattus exulans), house mouse (Mus musculus) and rabbit (Oryctolagus cuniculus cuniculus) from Ohinau and Motutapere Islands. Internal report, Hauraki Area Office. Thames, Department of Conservation.

de Lange PJ, McFadden I 1995. Additions and comments on the flora and fauna of Motukahakaha Island, Hauraki Gulf Auckland. Auckland Botanical Society Journal 50: 22-26. [NOTE this article actually refers to Ruthe Islet south of Rotoroa, not Motukahakaha which is north of Rotoroa.]

Eadie F, Broome K 1990. Ecological survey of northern bush Great Barrier 1986/87. Internal report, Auckland Conservancy. Auckland, Department of Conservation.

Fewster RM, Miller SD, Ritchie J 2011. DNA profiling-a management tool for rat eradication. In: Veitch CR, Clout $\mathrm{MN}$, Towns DR eds Island invasives: eradication and management. Gland, Switzerland, IUCN. Pp. 426-431.

GBI SOE 2010. 14 Terrestrial mammals \& mammalian pests. In: Great Barrier Island (Aotea) State of the Environment Report 2010. Unpublished report, Great Barrier Island Charitable Trust.

Glassey M 2004. A historical and ecological survey of Hauturu Island, Whangamata. Unpublished dissertation for Bachelor in Applied Science. Tauranga, Bay of Plenty Polytechnic.

Griffiths R, Buchanan F, Broome K, Neilsen J, Brown D, Weakley M 2015. Successful eradication of invasive vertebrates on Rangitoto and Motutapu Islands, New Zealand. Biological Invasions 17: 1355-1369.

Julian A 1992. The vegetation pattern of Rangitoto. PhD thesis. Auckland, University of Auckland. 297 p.

Lee M 1999. Biota of seven islets off Waiheke Island, Inner Hauraki Gulf. Tane 37: 99-136.

MacKay JWB 2011. Improving the success of mouse eradication attempts on islands. PhD thesis. Auckland, University of Auckland. 119 p.

MacKay JWB 2014. Mouse eradication on Motuketekete Island, Hauraki Gulf. Wildland Consultants Ltd.

MacKay JWB, Murphy EC, Anderson SH, Russell JC, Hauber ME, Wilson DJ, Clout MN 2011. A successful mouse eradication explained by site-specific population data. In: Veitch CR, Clout MN, Towns DR eds Island invasives: eradication and management. Gland, Switzerland, IUCN. Pp. 198-203.

McCallum J 1986. Evidence of predation by kiore upon lizards from the Mokohinau Islands. New Zealand Journal of Ecology 9: 83-87.

McFadden I 1992a. Eradication of kiore (Rattus exulans) from Double Island, Mercury Group in northern New Zealand.
Science and Research Internal Report No. 130. Wellington, Department of Conservation. $12 \mathrm{p}$.

McFadden I 1992b. Cost effective kiore eradication. In: Veitch CR, Fitzgerald M, Innes J, Murphy eds Proceedings of the national predator management workshop. Threatened Species Unit Occasional Publication No. 3. Wellington, Department of Conservation. $31 \mathrm{p}$.

McFadden I, Greene T 1994. Using brodifacoum to eradicate kiore (Rattus exulans) from Burgess Island and the Knights group of the Mokohinau Islands. Science and Research Series No. 70. Wellington, Department of Conservation. $18 \mathrm{p}$.

McFadden I, Towns DR 1991. Eradication campaigns against kiore (Rattus exulans) on Rurima Rocks and Korapuki, northern New Zealand. Science and Research Internal Report No. 97. Wellington, Department of Conservation. $18 \mathrm{p}$.

McIlroy JC 1990. Feral pig. In: King CM ed The handbook of New Zealand mammals. Auckland, Oxford University Press. Pp. 358-372.

Merton DV 1970. The rehabilitation of Cuvier Island. Wildlife 1970 - A Review: 5-8.

Moors PJ 1981. Norway rat studies on the Noises Islands, and proposals for future rat research. Internal report, file WIL 30/3/35. Wellington, Department of Conservation.

Moors PJ 1985a. Norway rats (Rattus norvegicus) on the Noises and Motukawao Islands, Hauraki Gulf, New Zealand. New Zealand Journal of Ecology 8: 37-54.

Moors PJ 1985b. Eradication campaigns against Rattus norvegicus on the Noises Islands, New Zealand, using brodifacoum and 1080. International Council for Bird Preservation Technical Publication 3. Pp. 143-155.

Moors PJ 1987. Norway rats on Motuhoropapa Island, Noises Group, Hauraki Gulf. Internal report, file WIL 30/3/35. Wellington, Department of Conservation.

Mowbray SC 2002. Eradication of introduced Australian marsupials (brushtail possum and brushtailed rock wallaby) from Rangitoto and Motutapu Islands, New Zealand. In: Veitch CR, Clout MN eds Turning the tide: the eradication of invasive species. IUCN SSC Invasive Species Specialist Group. Gland, Switzerland and Cambridge, UK, IUCN. Pp. 226-232.

Nanning C 2015. Rabbits on Motukorea Island. Internal report, file 1557793. Auckland, Department of Conservation.

Nathan HW, Clout MN, MacKay JWB, Murphy EC, Russell JC 2015. Experimental island invasion of house mice. Population Ecology 57: 363-371.

Newman DG 1985. The apparent loss of the Whenuakura Island tuatara population, Whangamata Islands wildlife sanctuary. Internal Report, file WIL 35/2/13. Wellington, Department of Conservation.

Ramón-Laca A, Gleeson D 2014. Use of forensic genetics to detect a potential incursion of the brushtail possum onto Great Barrier Island. New Zealand Journal of Ecology 38: $152-155$.

Reynolds K 2015. Detection probabilities of mice to enable efficient management. Unpublished MSc thesis. Auckland, University of Auckland.

Ritchie J 2015. Rat incursion biosecurity notes. Unpublished report prepared for Rotoroa Trust.

Rowan G 2013. Motu Kaikoura Review Report. Unpublished report prepared for Motu Kaikoura Trust.

Russell JC, MacKay JWB, Abdelkrim J 2009. Insular pest control within a metapopulation context. Biological 
Conservation 142: 1404-1410.

Russell JC, Sunde F, Samaniego A 2011. Rodent and seabird monitoring on Rotoroa Island. Unpublished report prepared for The Rotoroa Trust.

Russell JC, Towns DR, Anderson SH, Clout MN 2005. Intercepting the first rat ashore. Nature 437: 1107.

Tennyson AJD, Cameron EK, Taylor GA 1997. Fauna, flora and history of Moturekareka, Motutara and Kohatutara Islands, Hauraki Gulf. Tane 33: 27-56.

Tennyson AJD, Taylor GA 1999. History, flora and fauna of Te Haupa (Saddle) Island, Hauraki Gulf. Tane 37: 69-89.

Thorpe R 1997. Eradication of kiore from Middle Chain Island, Alderman Islands. Ecological Management 5: 1-4.

Towns D 2002. Interactions between geckos, honeydew scale insects and host plants revealed on islands in northern New Zealand following eradication of introduced rats and rabbits. In: Veitch CR, Clout MN eds Turning the tide: the eradication of invasive species. IUCN SSC Invasive Species Specialist Group. Gland, Switzerland and Cambridge, UK, IUCN. Pp. 329-335.

Towns D, McFadden I, Lovegrove T 1993. Offshore islands cooperative conservation project with ICICrop Care Division: Phase One (Stanley Island). Science and Research Internal Report No 138. Wellington, Department of Conservation. $24 \mathrm{p}$.

Towns D, McFadden I, Thomson P 1995. Offshore islands co-operative conservation project with ICI Crop Care Division: Phase Three (Cuvier Island). Science and Research Internal Report No 150. Wellington, Department of Conservation. $13 \mathrm{p}$.

Towns D, McFadden I, Thomson P, Robertson H, Colbourne R 1994. Offshore islands co-operative conservation project with ICI Crop Care Division: Phase Two (Red Mercury Island). Science and Research Internal Report No 142. Wellington, Department of Conservation. $12 \mathrm{p}$.

Veale AJ 2013. The invasion ecology and molecular ecology of stoats (Mustela erminea) on New Zealand's islands: detecting and assessing migration. $\mathrm{PhD}$ thesis. Auckland, University of Auckland. $173 \mathrm{p}$.

Veale AJ, Clout MN, Gleeson DM 2012a. Genetic population assignment reveals a long-distance incursion to an island by a stoat (Mustela erminea). Biological Invasions 14: $735-742$.
Veale AJ, Hannaford OD, Russell JC, Clout MN 2012b. Modelling the distribution of stoats on New Zealand offshore islands. New Zealand Journal of Ecology 36: 38-47.

Veitch CR 1973. Unpublished island survey report-Mokohinau Islands. Internal report, file WIL 16/1/*. Wellington, Department of Conservation.

Veitch CR 1985. Methods of eradicating feral cats from offshore islands in New Zealand. In: Moors PJ ed Conservation of island birds. ICBP Technical Publication No 3. Pp. 125-141.

Veitch CR 2001. The eradication of feral cats (Felis catus) from Little Barrier Island, New Zealand. New Zealand Journal of Zoology 28: 1-12.

Veitch CR 2002a. Eradication of Norway rats (Rattus norvegicus) and house mouse (Mus musculus) from Browns Island (Motukorea), Hauraki Gulf, New Zealand. In: Veitch $\mathrm{CR}$, Clout MN eds Turning the tide: the eradication of invasive species. IUCN SSC Invasive Species Specialist Group. Gland, Switzerland and Cambridge, UK, IUCN. Pp. 350-352.

Veitch CR 2002b. Eradication of Norway rats (Rattus norvegicus) and house mouse (Mus musculus) from Motuihe Island, New Zealand. In: Veitch CR, Clout MN eds Turning the tide: the eradication of invasive species. IUCN SSC Invasive Species Specialist Group. Gland, Switzerland and Cambridge, UK, IUCN. Pp. 353-356.

Veitch CR 2002c. Eradication of Pacific rats (Rattus exulans) from Fanal Island, New Zealand. In: Veitch CR, Clout MN eds Turning the tide: the eradication of invasive species. IUCN SSC Invasive Species Specialist Group. Gland, Switzerland and Cambridge, UK, IUCN. Pp. 357-359.

Veitch CR 2002d. Eradication of Pacific rats (Rattus exulans) from Tiritiri Matangi Island, Hauraki Gulf, New Zealand. In: Veitch CR, Clout MN eds Turning the tide: the eradication of invasive species. IUCN SSC Invasive Species Specialist Group. Gland, Switzerland and Cambridge, UK, IUCN. Pp. 360-364.

Wilson G 2003. Unpublished file notes on the eradication of Norway rats from The Noises. File fau 609-01. Auckland, Department of Conservation. 